\title{
An exegetical analysis of the vision of peace in the Book of Isaiah (2:1-5)
}

\begin{tabular}{|c|c|}
\hline $\begin{array}{l}\text { Author: } \\
\text { Alphonso Gro }\end{array}$ & newald ${ }^{1}$ \\
\hline $\begin{array}{l}\text { Affiliation: } \\
{ }^{1} \text { Department } \\
\text { Testament Stu } \\
\text { of Pretoria, So }\end{array}$ & $\begin{array}{l}\text { f Old } \\
\text { dies, University } \\
\text { uth Africa }\end{array}$ \\
\hline $\begin{array}{l}\text { Corresponden } \\
\text { Alphonso Gro }\end{array}$ & $\begin{array}{l}\text { ce to: } \\
\text { enewald }\end{array}$ \\
\hline $\begin{array}{l}\text { Email: } \\
\text { alphonso.groe } \\
\text { up.ac.za }\end{array}$ & newald@ \\
\hline $\begin{array}{l}\text { Postal address } \\
\text { Private Bag X2 } \\
0028 \text {, South A }\end{array}$ & $\begin{array}{l}\text { 0, Hatfield } \\
\text { frica }\end{array}$ \\
\hline $\begin{array}{l}\text { Dates: } \\
\text { Received: } 15 \\
\text { Accepted: } 19 \text { J } \\
\text { Published: } 18\end{array}$ & $\begin{array}{l}\text { May } 2013 \\
\text { une } 2013 \\
\text { Sept. } 2013\end{array}$ \\
\hline $\begin{array}{l}\text { How to cite th } \\
\text { Groenewald, } \\
\text { exegetical ana } \\
\text { vision of peac } \\
\text { of Isaiah ( } 2: 1- \\
\text { et Ecclesia } 34 \text { ( } \\
7 \text { pages. http:/ } \\
10.4102 / \text { ve.v3 }\end{array}$ & $\begin{array}{l}\text { is article: } \\
\text { A., } 2013, \text { 'An } \\
\text { lysis of the } \\
\text { e in the Book } \\
\text { 5)', Verbum } \\
\text { 2), Art. \#866, } \\
\text { /dx.doi.org/ } \\
4 \text { i2.866 }\end{array}$ \\
\hline $\begin{array}{l}\text { Note: } \\
\text { This article is } \\
\text { Prof. Dr J.H. le } \\
\text { shaped the mi } \\
\text { generations of } \\
\text { being trained } \\
\text { at the Univers } \\
\text { He has consist } \\
\text { students and } \\
\text { the historical } \\
\text { of texts during } \\
\text { the focus was } \\
\text { synchronic un } \\
\text { the Hebrew te }\end{array}$ & $\begin{array}{l}\text { ledicated to } \\
\text { Roux, who has } \\
\text { nds of several } \\
\text { students } \\
\text { theologically } \\
\text { ity of Pretoria. } \\
\text { ently reminded } \\
\text { colleagues of } \\
\text { embeddedness } \\
\text { a time in which } \\
\text { mostly on a } \\
\text { derstanding of } \\
\text { xt. }\end{array}$ \\
\hline $\begin{array}{l}\text { Copyright: } \\
\text { (C) 2013. The A } \\
\text { Licensee: AOSI } \\
\text { OpenJournals. } \\
\text { is licensed und } \\
\text { Creative Comn } \\
\text { Attribution Lic }\end{array}$ & $\begin{array}{l}\text { IS } \\
\text { This work } \\
\text { ler the } \\
\text { nons } \\
\text { ense. }\end{array}$ \\
\hline Read online: & \\
\hline 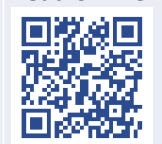 & $\begin{array}{l}\text { Scan this QR } \\
\text { code with your } \\
\text { smart phone or } \\
\text { mobile device } \\
\text { to read online. }\end{array}$ \\
\hline
\end{tabular}

The vision in Isaiah 2:1-5 of nations streaming to Zion in the days to come to receive Yahweh's Torah is one of the best-known texts in the entire Book of Isaiah. The chapter begins with the description of Yahweh, the universal Judge, who issues effective decrees and exercises authority over the earth from atop Mount Zion. The standards for the nations' relationships amongst themselves are set by Yahweh. The nations will learn peace and practice peace. The question of Israel's relationship to the nations is addressed in many texts in the Old Testament, but they do not offer a uniform opinion on this matter. The Book of Isaiah goes a step further than other texts: the Torah is also valid for the other nations. In this article the focus will be on Isaiah 2:1-5. The relationship of this text with other parts of the Book of Isaiah will also be addressed.

\section{Introduction}

The vision in Isaiah 2:1-5 of nations streaming to Zion in the days to come to receive Yahweh's Torah is possibly one of the best known texts in the entire Book of Isaiah. This chapter begins with the description of Yahweh, the universal Judge, who issues decrees and exercises authority over the earth from atop Mount Zion. Just as the Decalogue appears twice in the Pentateuch, the text about the pilgrimage of the nations to Zion appears twice in the prophetic canon. This oracle, which occurs in a slightly variant form in Micah $4: 1-3,{ }^{1}$ is one of the classic texts often cited as providing a biblical vision for world peace. The nations recognise the supremacy of Yahweh and go up to Jerusalem for instruction, because Yahweh's rulings are issued from there. The prophecy that the nations will one day beat their swords into ploughshares and their spears into pruning knives, that one nation will not take up its sword against another nation, and that they will cease to learn to war, is often taken as an imperative for how God's people should act (Roberts 2004:3).

The standards for the nations' relationships amongst themselves are thus set by Yahweh. Just as he settles disputes without choosing war, the nations should not turn to war to settle their disputes (Leclerc 2001:49). Political and economic oppression will come to an end, as well as hateful and divisive ideologies. The nations will learn peace and will practice it (Brueggemann 1998:25).

This peaceful situation does not acknowledge the voluntary decision of humble nations as such, but is a testimony to Yahweh's word that can compel nations to bring about peace. His worldwide rule causes all the nations to live in peace and walk in his ways. Yahweh's word and Torah ${ }^{2}$ are instructive: they teach Israel to do good and all the nations to cease their warfare. The result of 'judging' rightly is a society living in justice and a world at peace (Leclerc 2001:49).

The question of Israel's relationship to the nations is addressed in many texts in the Old Testament, but they do not offer a uniform opinion on this matter. On the one hand we encounter texts which are in favour of a hermetic segregation between Israel and the nations, ${ }^{3}$ and on the other hand there are texts which are in favour of the inclusion of foreigners ${ }^{4}$ into the community (Fischer 2010:184). In the Book of Jonah, for example, the salvation of Israel's God is extended to include the nations. The Book of Isaiah even goes a step further: the status of election is not restricted to Israel alone; the cult and the validity of the Torah for the other nations are reflected upon (Fischer 2010:185). In this article the focus will be on one text within the Isaianic corpus, namely 2:1-5, and the perspective this text offers regarding the nations.

1.Compare also Fischer (2008:155-164); Müller (2011:177-191) and Schwienhorst-Schönberger (1993:107-125).

2.Kaiser (2010:60) infers as follows: 'Blicken wir auf die Juden, so haben sie anders als die griechisch-hellenistische Welt in der biblischen Zeiten keinen Begriff wie den der Barbaren als Bezeichnung aller Fremden entwickelt; denn für sie waren nicht Bildung und zivilisatorische Güter, sondern die Kenntnis und Befolgung der Thora als Ausdruck des angemessenen Verhaltens zu dem einzigen wahren Gott das entscheidende Kriterium für die Beurteilung von Menschen und Völkern.'

3.Cf. the Books of Ezra and Nehemiah, Genesis 27:46-28:9; Numbers 25:6-15 and Deuteronomy 23:4-7.

4.Cf. the Books of Ruth and Jonah; Genesis 24 and Genesis 38. 


\section{Detail analysis}

\section{Translation}

v. 1: The word that Isaiah son of Amoz saw (in vision) concerning Judah and Jerusalem:

v. 2: And it will be in the sequel of days that the mountain of the house of Yahweh shall be established at the top of the mountains,

it shall be raised high above the hills; and all the nations shall stream to it.

v. 3: And many peoples shall come and shall say:

'Come, and let us go up to Yahweh's mountain,

to the house of Jacob's God;

and that He may teach us his ways,

and that we may walk in his paths'.

Yes, for out of Zion Torah shall go forth, and the word of Yahweh from Jerusalem.

v. 4: And He shall judge between the nations, and arbitrate for many peoples.

And they will beat their swords into ploughshares, and their spears into pruning knives.

Nation shall not take up the sword against nation, neither shall they learn war any more.

v. 5: O house of Jacob, come; and let us walk in the light of Yahweh!

\section{Isaiah 2:1}

This unit (2:1-5) commences with the superscription which stands apart from the material it introduces and which identifies the subsequent material as 'the word that Isaiah ben Amoz saw concerning Judah and Jerusalem'. It uses a common form and basic vocabulary and corresponds to the superscription at the beginning of a collection of prophetic words (cf. 1:1). The superscription in verse 1 clearly demarcates chapter 2 from the preceding chapter. However, there are still theological connections between 2:1-5 and chapter 1 , in spite of the fact that the superscription (2:1) and the insertion of 1:29-31 have weakened this link (Berges 1998:72). The motif which links the two parts of this overture together - namely the restoration of Zion and the pilgrimage of the nations - is defined as follows: 'the word of Yahweh/ the Torah of our God' (1:10) and 'the Torah/the word of Yahweh' (2:3) (Beuken 2003:89).

Isaiah 2:1 ascribes the origin of this word to Isaiah ben Amoz rather than a divine source. For redactors of this superscription it is important to claim that this perspective of Zion's future, which is without any nationalistic goals, actually belongs to the prophet Isaiah of 8th-century Jerusalem (Watts 2005:4142). Given the fact that the oracle which follows is also found in the collection ascribed to Micah, Isaiah's contemporary, the suggestion would be that this 'title' stresses the oracle's Isaianic origin (Ackroyd 1963:320). ${ }^{6}$ The superscription

5.Author's own translation.

6.Diachronically the superscription thus explains the relation to the Micah text. In this regard Beuken (2003:89) infers as follows: 'Weil der Text von 2,2-4 auch in Mi 4,13 begegnet, hat die Redaktion bei 2,1-4 die Randnotiz hinzugefügt, dieses Orake stamme tatsächlich von Jesaja! See also Fischer (1995:24) and Van Wieringen (2006:47). Contrasting (2006:47). Contrastingly Berges (1998:71) regards the Micah oracle as the original ... da $\beta$ eben diese Redaktoren auch 2,2-4 aus der Micha-Rolle übernahmen .... Both in faver (2011:177-191) and Schwienhorst-Schonberger (1993.107-125) also argue in favour of a preference for the book of Micah as the primary context of these verses. I only take cognisance of these different perspectives, but will not go into these discussions in more detail here. belongs to an editor who was aware of the problem of the double occurrence and affirmed his belief that the oracle was of genuine Isaianic origin. ${ }^{7}$ However, it says nothing about writing: Isaiah son of $\mathrm{Amoz}$ is nowhere pictured as a writing prophet. The words instead claim that the ideas in the book are related to Isaiah of Jerusalem of the 8th century BCE.

This verse cannot serve simply as the introduction to the passage which immediately follows it and therefore constitutes the first subunit of Isaiah 2:1-4:6 (Blenkinsopp 2000:190; Sweeney 1988:135; Sweeney 1996a:97). ${ }^{8}$ It mentions Judah and Jerusalem, which indicates that it does not relate solely to the Jerusalem-oriented unit in verses $2-5$, but to the following material as well. Chapters 2, 3 and 4 are all ultimately concerned with Judah and Jerusalem. This superscription thus leaves aside the undoubted wider application of the chapters to the Northern Kingdom of Israel (Ephraim), to Syria, and to other non-Israelite nations (Clements 1980:38). These chapters discuss the purification and restoration of Jerusalem and Judah so that Zion can become Yahweh's capital for ruling the whole world (Sweeney 1988:134).

When it is read as the title of chapters 2-4, it claims Isaiah's inspiration for the theme of Yahweh's reign on Mount Zion and its utmost position $(2: 2-5)$, and the theme of the dire results of the Day of Yahweh on Israel (2:6-8), on humankind and over the 'land' (2:9-22). It portrays a vision of Yahweh's dealings with Jerusalem, beginning with a trial and ending with a thorough cleansing of the city (chapters 3-4) (Watts 2005:42).

In 2:2 the time frame is qualified as 'after these days' or 'in the sequel of days', which probably refers to the Judah and Jerusalem of chapters 40 onwards. The vision has thus chosen words appropriate to the period of kingdoms and to the exilic and post-exilic periods.

\section{Isaiah 2:2-5 \\ Introduction}

Scholars generally agree that verses $2-4$ belong together, but they disagree on the relationship of verse 5 to this unit (Sweeney 1988:135). Some therefore favour ending the unit with verse 4 , and regard verse 5 as an editorial link with the oracle beginning in verse $6 .{ }^{9}$ Others see verse 5 as an editorial

7.Cf. Schmid (2011:61): 'Im jetzigen Zusammenhang kennzeichnet die Überschrift in 2,1 besonders das nachfolgende Wort Jes 2,2-5, das auch in Mi 4,1-5 begegnet ... als Jesajaprophetie.'

8. However, there is little agreement between scholars as to how much this heading is meant to introduce. Williamson (2006:163) lists the whole array of opinions on this matter. According to him the occurrence of a similar form of heading in chapter 13:1 is an indication that chapters $2-12$ may be the outer limit which can be considered. His synchronic analysis has also confirmed this conclusion.

9.Duhm (1914:17) infers as follows: ' 5 paßt weder in der Form noch im Inhalt zum folgenden und ist nur vorgesetzt, um zu verhüten, da $\beta$ kî von v. 6 eine geradezu absurde Fortsetzung von v. 2-4 liefere...'. Sweeney (1996a:97-98) follows Duhm in this regard and concludes as follows: 'The boundaries of this unit are determined by its future orientation, its focus on Zion and the nations, the $3^{\text {rd }}$-person descriptive language employed throughout the passage, and the absence of any specific indication of its addressee. Although many scholars maintain that 2.5 is part of this unit beause of its lexical similarities and its idyllic contents, this view must this unit because of its be rejected. The lack of a syntactical link between verse 4 and 5 , the use of a imperative address to the "house of Jacob" (19:0) sub-unit within chs.2-4. Compare also Berges (1998.73); Brueggemann (1998:2325); Landy (2003:317); Leclerc (2001:47); Sweeney (1996a:98); Watts (2005:41-42 and Williamson (2006:166f.). 
link with verse $6 \mathrm{ff}$. , but end the unit with verse 5 (Kaiser 1983:52, 56; Wildberger 1972:77-78). Still others see verses 2-5 as a distinct unit (Clements 1980:39, 42; Lohfink 1994: 40-43). According to Sweeney (1988:135), it seems as if verse 5 was formed with verse 3 as a model which might indicate that it belongs with verse $2-4$ as a unit. There is a similar syntactic arrangement of imperative verb, waw-consecutive, and first person plural imperfect verb in verse 3 and verse 5 . This verse is an invitation to Jacob to join with Yahweh (Sweeney 1988:138).

These verses express a picture of the future exaltation of Jerusalem and Mount Zion. It is a future promise of a role that they would fulfil in the days to come. It may be held to presuppose Deutero-Isaiah's surprising offer of salvation to the nations $(42: 1-4 ; 45: 22-25 ; 49: 1-6)$, linked to the descriptions of the pilgrimage of the nations to Jerusalem which we also find in Isaiah 45:14-21; 60:1-18 and 61:5-7 (Beuken 2003:89; Clements 1980:40). It draws upon traditions concerning the myth of the cosmic mountain which stood at the centre of the world, where divine order and truth originated and were given to the world.

\section{Verse 2}

Isaiah 2:2-4 pictures the situation of the mountain of Yahweh's house (i.e. Zion's Temple Mount) in the 'sequel of days ${ }^{\prime} .^{10}$ The emphasis may here be on the end of the days as they are currently experienced, characterised by enmity and war, and so especially on the transition to a new era or phase or history (Williamson 2006:180). The prophets indeed speak about a better future time, but not of the eschaton [end time]; it becomes a term for the end of days when that concept develops (Blenkinsopp 2000:190; Fischer 1995:25). ${ }^{11}$

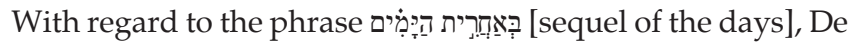
Vries (1995) infers as follows:

Our assessment has been that the poetic material it introduces is secondary in each context and dates from the late exilic or early postexilic period, having been composed for the purpose of providing the following collections of judgment oracles with a counterbalancing announcement of salvation, implicitly for the inhabitants of Jerusalem but explicitly for foreign nations. (p. 119)

'The mountain of the house of Yahweh' refers to Zion and the temple (Watts 2005:46). ${ }^{12}$ There was a widespread belief in the ancient world which associated mountains with proximity to, or even a representation of, the abode of the gods (Beuken 2003:91; Williamson 2006:181). Older mythology was undoubtedly taken over by Israel in her temple worship, as may be clearly seen in Psalms 46 and 48. The prophet makes creative use of such language in order to assert that 10.Cf. De Vries (1995:89): '... this refers to what is ostensibly a distant future'.

11.With regard to this indication of time, Beuken (2003:90) postulates as follows: Die Zeitbestimming »in zukünftigen Tagen « verweist nicht auf die eschatologische Vollendung der Geschichte, sondern auf eine noch entferne Zukunft, die aber einem Heute entspringt, was sich in diesem Fall konkret auf die Rückkehr Zions zu Recht und Gerechtigkeit bezieht.... Inhaltlich gesehen stellt sie die jede Erfahrung übersteigende Vision vom Zion als dem geistlichen Zentrum der Welt Erfahrung übersteigende Vision vom Zion als dem geistlichen Zentrum der Welt Wiederaufbau der Stadt, den JHWH herbeiführen wird (s. zu 1.18).'

12.The expression 'the mountain of the house of Yahweh' occurs only in Isaiah 2:2; Micah 4:1 and in 2 Chronicles 33:15. Compare Fischer (1995:26) with regard to the Chronicles text: '... handelt es sich hier jedenfalls um den von Fremdkulten gereinigten Tempelberg'. the time is coming when the superiority of Zion's God and his truth will be seen and acknowledged universally. And the appearance of God's earthly abode, which now fails to correspond with what was believed to be its true nature, will be changed to reflect that present hidden reality. Zion, as a microcosm of the created world, was already believed to be 'established' - as is clear from for example Psalm 48:9 (Eng. 48:8) - and consequently it could never be moved (Ps 46:6[5]) in the face of any attack.

Isaiah 2:2 introduces a motif that runs through most of the Book of Isaiah (excluding chapters 38-55). The mountain will be established as the most important and respected pilgrimage destination for 'all nations'. 'Established' is a key word. The established order of nature and of political and social forms is being turned upside down (Watts 2005:47). The first move toward restoring order and confidence will be to firmly fix the temple in its place on Zion. Its position is to be at the very top of the mountains and all things that mountains stand for.

Therefore, for the Book of Isaiah it is a terrible sin 'to forget the mount of my holiness' (Is 65:11). Zion will be the cult centre for a huge number of international believers in an era of peace for everyone. Isaiah 25:6-8 places the turning point for human history on the mountain of God:

On this mountain the Lord of hosts will make for all peoples a feast of rich food, a feast of well-aged wines strained clear. And he will destroy on this mountain the shroud that is cast over all peoples, the sheet that is spread over all nations; he will swallow up death forever. Then the Lord will wipe away the tears from all faces, and the disgrace of his people he will take away from all the earth, for the Lord has spoken. (New Revised Standard Version [NRSV])

The reason why Zion will surpass everything else is that it will become the most important - or even the only - locus of oracles in the world (Lohfink 1994:41). In this instance we need to regard the lower hills as analogous to the temples and oracle loci of other gods throughout the world. Ultimately it is God and the gods who will be in view. The gods of these other oracle loci will become powerless at the envisaged point of history as oracles offering help will no longer go forth from there. The starting point for the word about the pilgrimage of the nations is the impending disappearance of the gods outside Israel. As is known, that is an important theme from Isaiah 40 onwards.

\section{Verse 3}

The goal of the journey is the 'mountain of the Lord' (as in v. 2) which is now explicitly defined further as the 'house of the God of Jacob'. This divine title does not occur elsewhere in the prophets (apart from the parallel in Micah), but it is frequent in the Psalms of Zion and others from the same milieu and refers to Yahweh as God of all Israel, based in the Jerusalem temple (Sweeney 1996a:88; Williamson 2006:183). Of the many reasons why one might undertake a pilgrimage to the sanctuary, only one is mentioned here, namely the search for Torah. Before this word, and leading to it, stands the verb ירה [to teach] which has the same root. In the MT this 
word sketches a consistent picture: God is the one who acts. Just as Israel received God's instruction at Sinai, the nations will be taught and instructed at Mount Zion through the Book of Isaiah (Berges 2001:59).

Once Zion is restored, Torah will go forth from her to the nations. Here for the first time she plays a role regarding the nations. The expression יצא [to go forth] reminds one of the temple vision in Ezekiel 47, where יצא is constantly used to describe the flowing, life-assuring waters from the altar of the temple (Berges 2001:59). Consequently, Isaiah 2:3 could be translated as follows: 'for out of Zion flows forth the Torah' as lifegiving force. Here by the waters of the Torah the just can plant their roots and yield fruits in its season (Ps 1; Jr 17:8). It seems to be no coincidence that the song of thanksgiving in Isaiah 12, at the very end of the first main section of the book, also refers to water in relation to Zion and the nations (Is 12:3, 6).

Furthermore, the expression 'out of Zion flows forth Torah' (Is 2:3) should be seen in connection with the mission of the Ebed [Servant] to bring forth justice to the nations (42:1). Zion and the Ebed fulfil a similar task, not only in their suffering, but also in their mission to the nations. The difference is, however, that the Ebed has to bring justice to the people, whereas Zion will receive the nations who will come to her (Williamson [1994] 2005:152).

The function of the new temple centres on Torah. ${ }^{13}$ Jerusalem will be known primarily for the temple where Yahweh abides, and this temple is to serve as a gathering place for learning Yahweh's ways and paths (Watts 2005:48). Parallel to the Torah of the pilgrimage of the nations, we find the 'word of Yahweh' that now goes forth from Jerusalem (Lohfink 1994:40).

The word about the pilgrimage of the nations begins with the symbolic picturing of mountains and hills (v. 2). Next to Zion there are only hills, which do not match its height. The world landscape changes as Zion becomes the highest of the mountains. ${ }^{14}$ If in this context the word Torah is so clearly emphasised, that suggests that the Torah that is directed to the nations from Jerusalem is connected with that peaceestablishing Torah possessed by Israel that lives on Zion (Lohfink 1994:42).

\section{Verse 4}

With this verse we finally reach the specific goal of the nations' quest, namely that God should 'judge between' and 'arbitrate' for them. Yahweh will decide on the issues that are concerning the peoples (Watts 2005:48; Williamson

13.Regarding the function of Zion and the temple Beuken (2003:92) postulates as follows: 'Die Völkerwallfahrt soll dazu führen, dass sie ihre durch Gott festgelegte Rolle auch tatsächlich einnimmt. Von ihr aus soll eine Bewegung zu den Völkern in Gang kommen: Sie ist dazu bestimmt, Ausgangspunkt für JHWHs Tora zu sein.'

14.With regard to election of Zion as the mountain of Yahweh Beuken (2003:91) infers as follows: 'Zions heilsgeschichtliche Erwählung als Berg des Hauses JHWHs zieht eine geographische Verwandlung nach sich: Der Berg wird nicht nur hoch, sondern er wird der höchste der Berge sein. Das Thema spielt im Verlauf des Jesajabuches er wird der höchste der Berge sein. Das Thema spielt im Verlauf des Jesajabuches
eine Rolle, wo "Berge/Hügel « den Widerstand gegen die göttliche Autorität eine Rolle, wo "Berge/Hügel« den Widerstand gegen die göttliche Autorit
symbolisieren, letztlich aber sein befreiendes Wirken an Israel anerkennen.'
2006:185). A significant element of the role of the pre-exilic king was that he should exercise divinely given wisdom in the settling of disputes between his subjects. By extension, cases of international dispute will be decided by the Great King, the God of Israel.

The background of this oracle is in the legal tradition and it takes as an example the process of the High Court of Arbitration as described in the Deuteronomic Law. It offers conspicuous parallels to Deuteronomy 17:8-11; specifically with regard to the word pair 'Torah' or 'word' in Deuteronomy 17:11. The scene described here is in essence the same, but in the prophetic oracle it has moved from the private realm to the dimension of international relationships. Everyday legal practice and custom, as envisioned and legislated by the Deuteronomic code with its central abode for the Deity, is reflected and magnified to produce the prophetic picture of the future of international relationships (Schwartz 1998:19-21). The nations will thus also experience the benefits of the Torah in the way Israel enjoys them. Was it not prophesied by Moses that the nations would envy Israel because of the Torah (Dt 4:5-8)? This, however, can only happen on the precondition that they protect the Torah in their hearts (Beuken 2003:93).

This verse assumes the sovereignty of Yahweh over the nations and the peoples - a point that chapter 41 will develop further. As this text continues, it clearly presses forward to questions of human conflict. The consequences of the nations' implementation of God's decisions are spelt out in terms of a utopian vision of peace. It is presented as the natural consequence of the nations seeking, receiving and acting upon God's instruction and arbitration. ${ }^{15}$ As one reads further, the surpassing height of Zion seems have something to do with the peace that the nations are unable to find amongst themselves, but which they seek and then obtain from Zion (Lohfink 1994:42).

The functions that Yahweh has performed in his relationship with Israel will now be applied universally. Armaments and wars will be unnecessary as his decisions will settle all disputes between peoples and nations. Wars will therefore cease. When the population of the countryside is called to arms, as evidenced in Joel 4:9-10 (Eng. 3:9-10), they are told to 'beat your ploughshares into swords, and your pruning knives into spears' (Williamson 2006:186). In Isaiah's vision, the belligerent peoples will reverse this process, and turn their implements of warfare back into implements of agriculture, as they were originally (Schwartz 1998:17). Nations will no longer lift up a sword against each other, and they will not learn to fight any more.

\section{Verse 5}

It has already been remarked that verse 5 was formed with verse 3 as a model (Sweeney 1988:135). The expression 'come, and let us walk' is undoubtedly modelled on the similar 'come, let us go up' in verse 3. This summons makes 15.Beuken (2003:93) formulates this assumption as follows: 'Die Initiative zum Frieden geht als Frucht von JHWHs Tora bei den Völkern von diesen selbst aus.' 
it clear that the prophet is on the side of his people and his aim is to encourage them to live as worthy examples of the principles which have been introduced in verses $2-4$. Verse 5 discloses the purpose of the redactional insertion of these verses in the Book of Isaiah, namely to inspire the community to be obedient to Yahweh's will in the face of the coming judgement, by holding forth a perspective of the future glorification of the city of Yahweh (Kaiser 1983:50).

The address 'house of Jacob', which is here used for the whole of Israel, stresses the religious and moral connections existing between the patriarch and his descendants (cf. e.g. Gn 46:27; Ex 19:3; Ps 114:1). ${ }^{16}$ The venture of the covenant which Yahweh made with Jacob is still continuing (Beuken 2003:94).

The fact that in future days Zion will stand higher than all other mountains because Torah reigns in Jerusalem, becomes even clearer when one takes a look at this last verse with which this prophetic word closes. The mountain, which with the house of Yahweh towers above the other hills, is dependent on the fate of the Torah in Israel. Only when it begins to give light, then Zion-Torah can go forth from Israel into the world of the nations. Thereby, at least in Isaiah, the conclusion of the word makes it clear that the Torah of 2:3 also has an inner connection with the Torah given to Israel by its God. The house of Jacob ${ }^{17}$ must begin to become a just society. This demand is made now, and it is made in view of what is promised for the 'days to come' (v. 2). The logic is: they must now become a just society so that what God will bring about in days to come, can thereby begin. ${ }^{18}$

In this verse (2:5) the 'house of Jacob' is called upon to walk in 'the light of Yahweh'. The only element for which there is no immediate verbal trigger in the surrounding context is the phrase 'in the light of Yahweh'. In use here seems to be the metaphor of the Sun-god, who is also the God of righteousness (Lohfink 1994:42). ${ }^{19}$ According to Taylor (1993:257) there is more than enough biblical and archaeological evidence that a close relationship existed between Yahweh and the sun: a 'solar' character was often presumed for Yahweh. ${ }^{20}$ In many

16.According to Blenkinsopp (2000:191) it is hardly coincidental that the story of the patriarch Jacob's exile in Mesopotamia and return (Gn 25-35) mirrors the experience of deported and repatriated Judeans beginning in the 6th century BCE. Compare also Kaiser (1983:56).

17. Noteworthy is the fact that this name occurs some twenty times in Isaiah $40-55$ to refer to the exiled Israelites (Williamson 2006:188).

18.Berges (1998:73) formulates this summons as follows: 'Mit Jes 2,5 machen die Redaktoren die Verpflichtung deutlich, die für die nachexilische Gemeinde in Jerusalem aus der Verheißung einer Völkerwallfahrt zum Zion erwächst: Die Gabe wird als Aufgabe anerkannt und angenommen.'

19.In this regard Keel and Uehlinger (1992:464-465) indicate that the image of the solar god of heaven was characteristic not only of Israel, but also of Judah during the second half of the 8th century. There is a crowned solar disk, flanked by uraei, on a seal that belonged to a minister of King Ahaz. Four-winged uraei were typical in Judah. In his vision, Isaiah saw Yahweh surrounded by six-winged uraei (Isaiah 6). The winged solar disks and the four-winged scarabs appearing on Hezekiah's roya seals may have symbolised Yahweh as sun god and indirectly indicated that the sun god sanctioned the Davidic Kingdom.

20.According to Smith (2002:157-158) solar language for Yahweh apparently developed in two stages. Firstly, it originated as part of the Canaanite religious influence, and mo in thence, and more generally Near Eastern heritage of divine language. Secondly, in the sun che in Assur, Babylon and Ugarit. Compare also Arneth (2000.1-17, 109f.); Janowski (1989); Keel and Uehlinger (1992:318-320); Keel and Uehlinger (1994:269-306); Langer (1989:33-51, 152-155); Stähli (1985:39f.). instances the sun actually represented Yahweh as a kind of 'icon'. The association between Yahweh and the sun did not only occur in one or even two obscure contexts, but was well integrated into the religion of ancient Israel. Solar Yahwism during the monarchy was a feature of royal religion. The sun was understood to be a tangible expression of Yahweh in ancient Israel (Taylor 1993:259-260).

The expression 'the light of Yahweh' seems to be the editor's way of contemplating or characterising the 'ways', 'paths', 'instruction' and 'word' of verse 3 (Williamson 2006:187). Light is a prominent image for salvation (broadly spoken) in all parts of the Book of Isaiah (Clements 1996:68). ${ }^{21}$ In the earlier material, 9:1 (Eng. 9:2)22 is a particularly significant example. The use of 'light' occurs, however, most frequently and creatively in Deutero-Isaiah (e.g. 42:16; 45:7; 49:9), whilst the uses in Trito-Isaiah seem to draw on the earlier examples in the book. It is significant that it occurs as a major theme of the redactional joins in 2:5, at 5:3023 and at 9:1 (Eng. 9:2), all of which can simply be associated with the late exilic or early post-exilic redaction of the first part of the book.

\section{Dating}

These verses have a prominent setting in the book as a whole. This prominence is confirmed by the fact this text is a collage of Zion themes and that its major themes are echoed later on, especially in the second half of the book (Williamson 2006:172). These verses outline a vision of the ideal Zion as the centre of God's peace-promoting rule of the whole earth. The general theme and outlook of the passage find their closest parallels in material from the late exilic and early postexilic periods, such as Isaiah 40-55; 56:6-8; 60 and 66:18-21. From a diachronic perspective three different motifs position themselves here at the entrance to the Book of Isaiah: Zion's significance fits Proto-Isaiah; the nations' acknowledgement of Yahweh fits Deutero-Isaiah, and the pilgrimage of the nations to Zion fits Trito-Isaiah (Beuken 2003:90).

The most likely date for this text's composition date cannot be easily determined with precision, but the post-exilic period probably mid to late 5th century (or even later?) - is the most likely (Blenkinsopp 2000:191; Clements 1980:40; Sweeney 1996a:97, 1996b:51). The phrase 'Judah and Jerusalem' which occurs in the new title in 2:1 also indicates a post-exilic origin (Ackroyd 1963:320). Diachronically the motif of 'Zion as the goal of the pilgrimage of the nations' $(2: 1-5)$ and Jerusalem as the place from which moral instruction radiates, fits well into the second Temple Period when Israel definitely became an ethnic entity within the Persian Empire (Beuken 2003:90; Blenkinsopp 2000:190).

21.With regard to the metaphorical usage of 'light' Beuken (2003:94) infers as follows "Licht" (אוֹ) ist im Jesajabuch eine Metapher für das durch Gott bewirkte Heil, während die Abwesenheit von Licht das Gericht umschreibt; dies gilt sowohl für Israel $(5,30 ; 9,1 ; 30,26 ; 42,16 ; 45,7 ; 58,8.10 ; 59,9)$ als auch für die Völker $(13,10$; $51,4 ; 60,3)$. JHWH selbst kann als Licht Israels auftreten $(10,17 ; 60,1.19 f$.$) . Kurzum:$ Der Prophet setzt Gottes Tora mit Gottes Heil gleich.

22.Isaiah 9:1 (Eng. 9:2) reads as follows: 'The people who walked in darkness have seen a great light; those who lived in a land of deep darkness - on them light has shined' (NRSV).

23.Isaiah 5:30 reads as follows: 'They will roar over in on that day, like the roaring of the sea. And if one look to the land - only darkness and distress; and the light grows dark with clouds' (NRSV). 
If the text is read on a synchronic level, the addition of these verses to the Book of Isaiah leads to the thematic coexistence of two themes, namely on the one hand the 'cleansing of Zion' in chapter 1, and on the other hand the 'pilgrimage of the nations' (2:2-4). If this addition is to be dated in the 5 th century (or later), the question arises whether this thematic concatenation does not reflect a strong protest against the religious policies of Ezra and Nehemiah who forced all men in mixed marriages to divorce from their foreign wives (Ezr 9-10; Neh 13:23-31). Their policies furthermore closed the ranks of the post-exilic Judean congregation for Yahweh followers from other nations - yes even for their fellow Yahweh followers from Samaria (Berges 1998:71).

The close literary connections between 2:1 and 13:1 could be an indication that the oracle of the pilgrimage of the nations in 2:2-4 should be read against the downfall of Babylon (Berges 1998:75-76). Isaiah 13:1 forms the introduction to the Babylon oracle in Isaiah 13-14. If this text does not refer to the peaceful takeover of Babylon by Cyrus in 538, it could be a reference to Xerxes' actions against Babylon in $482 .{ }^{24}$ This would make the incorporation of Isaiah $2: 1-5$ into the Book of Isaiah at a date after 482 a better possibility. The nations will not go to Babylon any more, as it was destroyed by Xerxes. Jeremiah 51:44 testifies to this event and says: 'I will punish Bel in Babylon, and make him disgorge what he has swallowed. The nations shall no longer stream to him; the wall of Babylon has fallen' (NRSV). They will instead go to Zion, to the house of the God of Jacob, in order to learn the Torah of peace, which will replace their instruments of war. This fits very well as a reaction to the battle in which the Persian empire finally defeated the power of the Babylonian empire.

\section{Conclusion}

Zion's final goal and purpose do not form part of the nationalistic dreams of either Israel or Judah (Watts 2005:49). The wish to be 'nations like other nations' (1 Sm 8:5) has been the cause of centuries of warfare and bloodshed as no righteousness and justice have come forth from this wish. Different parties in the Jerusalem in the final decades of the 6th and 5th century claimed God's promises for new forms of nationalistic struggles. The purpose of the Book of Isaiah - as is clearly formulated here at its onset - is to deny these claims (cf. 65:1-16) and to present an entirely different vision of Zion's destiny (Watts 2005:49). The city will be redeemed and will be equipped to become God's instrument. In Zion he will receive all the nations and peoples and teach them his ways. Zion's appeal will thus be religious and universal.

What is the role of God's people in this city? The rest of the Book of Isaiah addresses this question. God's people will include only those who are dedicated to Yahweh, 'servants

24.In 482 a revolt broke out against the Persian rule, but Xerxes suppressed this rebellion with force. These events certainly were received with enormous joy in rebellion with force. These events certainly were received with enormous joy in by th: Once again the archen we the would be heading for a new future. It certainly would have invoked new hope that at last, Yahweh would restore Zion to its formal glory, as well as rebuild the cities of Judah (Groenewald 2003:236). of Yahweh', from the remnants of Israel, Jerusalem and the nations. Justice, righteousness and obedience have been named as non-negotiable qualities which are needed for the city and its inhabitants. Faith and humility will be some of the virtues taught to the servants of Yahweh, the King of Zion and the God of Israel (Watts 2005:50).

This oracle at the beginning of chapter 2 anticipates Yahweh's initiative with his servant in Deutero-Isaiah and hereby adds a new chapter of Jacob's history to the Book of Isaiah (Beuken 2003:94). Although the patriarch Jacob was only the second son of an elected generation (Gn 25:19-26), he used a bit of cunning to get hold of his brother's birthright (Gn 25:29-34; 27:1-40). In Isaiah 2:1-5 Jacob's descendants also hold the second position after the nations in accepting Yahweh's Torah, but subsequently they will become the elected servant and are employed to be 'a light to the nations, that my salvation may reach to the end of the earth' (Is 49:6; cf. also 42:6).

It is therefore not surprising at all that the later tradition portrayed Isaiah as a man who was great and trustworthy in his visions. Sirach depicts Isaiah as a man who by his dauntless spirit saw the future and comforted the mourners in Zion. He revealed what was to occur to the end of time and the hidden things before they happened ( $\mathrm{Sr} 48: 24-25)$.

\section{Acknowledgements Competing interests}

The author declares that he has no financial or personal relationship(s) that may have inappropriately influenced him in writing this article.

\section{References}

Ackroyd, P.R., 1963, 'A note on Isaiah 2:1', ZAW 75, 320-321.

Arneth, M., 2000, Sonne der Gerechtigkeit. Studien zur Solarisierung der JahweReligion im Lichte von Psalm 72, Harrassowitz, Wiesbaden. (BZAR 1).

Berges, U., 1998, Das Buch Jesaja. Komposition und Endgestalt, Herder, Freiburg. (HBS 16).

Berges, U., 2001, 'Personifications and prophetic voices of Zion in Isaiah and beyond', in J.C. de Moor (ed.), The elusive prophet. The prophet as a historical person, literary character and anonymous artist, pp. 54-82, Brill, Leiden. (OTS XLV).

Beuken, W.A.M., 2003, Jesaja 1-12, Herder, Freiburg. (HThKAT).

Blenkinsopp, J., 2000, Isaiah 1-39, Doubleday, New York. (AncB 19).

Brueggemann, W., 1998, Isaiah 1-39, Westminster/John Knox, Louisville/London. (WBC).

Clements, R.E., 1980, Isaiah 1-39, Eerdmans, Grand Rapids. (NCB).

Clements, R.E., 1996, 'A light to the nations: A central theme of the book of Isaiah', in J.W. Watts \& P.R. House (eds.), Forming prophetic literature. Essays on Isaiah and the Twelve in honor of John D W Watts, pp. 57-69, Sheffield Academic Press, Sheffield. (JSOT.S 235).

De Vries, S.J., 1995, From Old Revelation to New. A Tradition-Historical and RedactionCritical Study of Temporal Transitions in Prophetic Prediction, Eerdmans, Grand Rapids.

Duhm, B., 1914, Das Buch Jesaja, 3rd edn., Vandenhoeck \& Ruprecht, Göttingen. (HK).

Fischer, I., 1995, Tora für Israel - Tora für die Völker. Das Konzept des Jesajabuches, Katholisches Bibelwerk, Stuttgart. (SBS 164).

Fischer, I., 2008, "World peace and "holy war" - two sides of the same theological concept: "YHWH as sole divine power" (a canonical-intertextual reading of Isaiah 2:1-5, Joel 4:9-21, and Micah 4:1-5)', in R. Cohen \& R. Westbrook (eds.), Isaiah's vision of peace in Biblical and modern international relations: Swords into plowshares, pp. 151-165, Palgrave MacMillan, New York.

Fischer, I., 2010, 'Israel und das Heil der Völker im Jesajabuch', in H. Frankemölle \& J. Wohlmuth (eds.), Das Heil der Anderen. Problemfeld "Judenmission", pp. 184208, Herder, Freiburg. (QD238). 
Groenewald, A., 2003, Psalm 69: Its structure, redaction and composition, Lit-Verlag, Münster. (ATM 18).

Janowski, B., 1989, Rettungsgewibheit und Epiphanie des Heils. Das Motiv der Hilfe Gottes »am Morgen " im Alten Orient und im Alten Testament. Band I: Alter Orient, Neukirchener Verlag, Neukirchen-Vluyn. (WMANT 59).

Kaiser, O., 1983, Isaiah 1-12, 2nd edn., SCM Press, London. (OTL).

Kaiser, O., 2010, Gott, Mensch und Geschichte. Studien zum Verständnis des Menschen und seiner Geschichte in der klassischen, biblischen und nachbiblischen Literatur, De Gruyter, Berlin/New York. (BZAW 413).

Keel, O. \& Uehlinger, C., 1992, Göttinnen, Götter und Gottessymbole. Neue Erkenntnisse zur Religionsgeschichte Kanaans und Israels aufgrund bislang unerschlossener ikonographischer Quellen, Herder, Freiburg. (QD 134).

Keel, O. \& Uehlinger, C., 1994, 'Jahwe und die Sonnengottheit von Jerusalem', in W. Dietrich \& M.A. Klopfenstein (eds.), Ein Gott allein? JHWH-Verehrung und biblischer Monotheismus im Kontext der israelitischen und altorientalischen Religionsgeschichte, pp. 269-306, Universitätsverlag, Fribourg. (ОВО 139).

Landy, F., 2003, 'Torah and anti-Torah: Isaiah 2:2-4 and 1:10-26', Biblical Interpretation 11, 317-334. http://dx.doi.org/10.1163/156851503322566750

Langer, B, 1989, Gott als 'Licht' in Israel und Mesopotamien. Eine Studie zu Jes 60,1 3.19f., Österreichisches Katholisches Bibelwerk, Klosterneuburg. (ÖBS 7).

Leclerc, T.L., 2001, Yahweh is exalted in justice. Solidarity and conflict in Isaiah, Fortress Press, Minneapolis.

Lohfink, N., 1994, 'Bund und Tora bei der Völkerwallfahrt (Jesajabuch und Psalm 25)', in N. Lohfink \& E. Zenger (eds.), Der Gott Israels und die Völker. Untersuchungen zum Jesajabuch und zu den Psalmen, pp. 37-83, Katholisches Bibelwerk, Stuttgart. (SBS 14).

Müller, R., 2011, 'Doubled prophecy: The pilgramage of the nations in Mic 4:1-5 and Isa 2:1-5', in H. von Weissenberg, J. Pakkal \& M. Marttila (eds.), Changes in Scripture. Rewriting and interpreting authoritative traditions in the second Temple Period, pp. 177-191, De Gruyter, Berlin/New York. (BZAW 419).

Roberts, J.J.M., 2004, 'The end of war in the Zion tradition: The imperialistic background of an Old Testament vision of world-wide peace', HBT 26, 2-22.
Schwartz, B.J., 1998, 'Torah from Zion. Isaiah's temple vision (Isaiah 2:1-4)', in A. Houtman, M.J.H.M. Poorthuis \& J. Schwartz (eds.), Sanctity of time and space in tradition and modernity, pp. 11-26, Brill, Leiden. (JChPS 1).

Schwienhorst-Schönberger, L., 1993, 'Zion - Ort der Tora. Überlegungen zu Mi 4,1-3', in F. Hahn et al. (eds.), Zion - Ort der Begegnung: Festschrift für Laurentius Klein zur Vollendung des 65. Lebensjahres, pp. 107-125, Hanstein, Bodenheim. (BBB 90).

Smith, M.S., 2002, The early history of God. Yahweh and the other deities in Ancient Israel, 2nd edn., Eerdmans, Grand Rapids.

Stähli, H.-P., 1985, Solare Elemente im Jahweglauben des Alten Testaments, Universitätsverlag, Fribourg. (OBO 66).

Schmid, K., 2011, Jesaja 1-23, Theologischer Verlag, Zürich. (Zürcher Bibelkommentare AT 19.1).

Sweeney, M.A., 1988, Isaiah 1-4 and the post-exilic understanding of the Isaianic tradition, Walter de Gruyter, Berlin. (BZAW 171).

Sweeney, M.A., 1996a, Isaiah 1-39, with an introduction to prophetic literature, Eerdmans, Grand Rapids. (FOTL 16).

Sweeney, M.A., 1996b, 'The book of Isaiah as prophetic Tora', in R.F. Melugin \& M.A Sweeney (eds.), New visions of Isaiah, pp. 50-67, Sheffield Academic Press, Sheffield. (JSOT.S 214).

Taylor, J.G., 1993, Yahweh and the sun. Biblical and archaeological evidence for sun worship in ancient Israel, Sheffield Academic Press, Sheffield. (JSOT.S 111).

Van Wieringen, A.L.H.M., 2006, The reader-oriented unity of the book of Isaiah, Skandalon, Vugt. (ACEBT.S 6).

Watts, J.D.W., 2005, Isaiah 1-33, revised edn., Thomas Nelson, Nashville. (WBC 24).

Wildberger, H., 1972, Jesaja 1-12, Neukirchener Verlag, Neukirchen-Vluyn. (BKAT X/1).

Williamson, H.G.M., [1994] 2005, The book called Isaiah. Deutero-Isaiah's role in composition and redaction, Clarendon Press, Oxford.

Williamson, H.G.M., 2006, Isaiah 1-5, T\&T Clark, London/New York. (ICC). 